\title{
悪性腫瘍の MRI
}

一化学療法効果について一

\author{
九州大学整形外科 \\ 山本卓 明-岩本幸 英 \\ 中馬広一・杉岡洋一
}

\section{Evaluation of Chemotherapeutic Efficacy by Magnetic Resonance Imaging}

by

\author{
Takuaki Yamamoto, Yukihide Iwamoto, Hirokazu Chuman \\ and Youichi Sugioka
}

Department of Orthopaedic Surgery Faculty of Medicine, Kyushu Univesity, Fukuoka Japan

\begin{abstract}
We reviewed magnetic resonance images (MRI) of eight patients with osteosarcoma and one patient with Ewing's sarcoma treated with preoperative chemotherapy. MRI was performed with a Signa 1.5-Tesla superconducting magnet. Comparisons were made between the percentage of tumor necrosis calculated by histologic maps of the surgical specimens and the following four items : first, changes of signal-intensity inside the tumors, second, the reduction of reactive zone surrounding the tumors, which shows a high intensity on $\mathrm{T} 2$-weighted images, third, the increase of clearness around the tumors, which shows a low intensity on $\mathrm{T} 1$ and $\mathrm{T} 2$ images and finally, the reduction in size of the extraosseous components of the tumors. A significant correlation was observed between the reduction and the percentage of tumor necrosis. The reduction in size of the extraosseous components of tumors may be useful in evaluating chemotherapeutic efficacy.
\end{abstract}

\section{は じめに}

MRI は，骨軟部腫瘍の補助的診断として久くこと のできないものとなってきた4),5),6),10). 従来, 化学 療法 (化療) 効果判定は, 臨床症状の変化, 単純X線, 血清アルカリホスファターゼ值, 血管造影, $\mathrm{CT}$ 等で なされてきたが2)，必ずしも十分に病巣の状態の変化 をとられているとはいい難い，今回われわれは，MRI のいかなる画像の変化が，化療効果判定として有用か 検討を加えてみた。

\section{対象症例及び方法}

対象症例は, 骨肉腫 8 例, Ewing 肉腫 1 例で, 化 学療法の内容は症例 $1 \sim 6$ には Cisplatin 動脈内注
入, 症例 7 - 8 には Methotrexate, Adriamycin, Cisplatin の全身化学療法, 症例 9 にはVincristin, Adriamycin, Cyclophosphamide の全身化学療法 を行った（表1）.

使用機種は原則として General Electric 社製 Signa 1.5 Tesla 超伝導 MRI 装置，パルス系列は，Spin Echo 法を用いた.

また，MRIの評価項目を 1 ．内部構造の変化， 2 ． 腫瘤辺縁の high intensity zone として促えられる 反応層の縮小， 3 ，骨外腫瘤辺緑の明瞭化，4．デジ タイザーで求めた最大割面面積の縮小で判定した骨外 腫瘤の縮小率，の 4 点とし，以上の項目について，化 療開始前の MRI 画像と手術直前の MRI 画像を同一 スライス面で比較した（表2）。そして，この評価項 
表 1 対象症例

\begin{tabular}{lccc}
\hline \hline Case & Tumor & Location & Chemotherapy \\
\hline 1. & Osteosarcoma Rt. Humerus, P & CDDP i.A \\
2. & " & Lt. Femur, D & " \\
3. & Lt. Femur, D & " \\
4. & Lt. Femur, D & " \\
5. & Rt. Femur, D & " \\
6. & Lt. Tibia, P & "Lt. Femur, D MTX. CDDP. ADR systemic \\
7. & Rt. Femur, D \\
8. & " & "
\end{tabular}

\section{表 2 MRI での評価項目}

1. 内部構造の変化

2. 反応層 (腫瘍辺縁の high intensity zone)

3. 骨外腫瘤辺縁の明暸化

4. 骨外腫瘤の縮小

（デジタイザーによる最大割面面積の縮小）

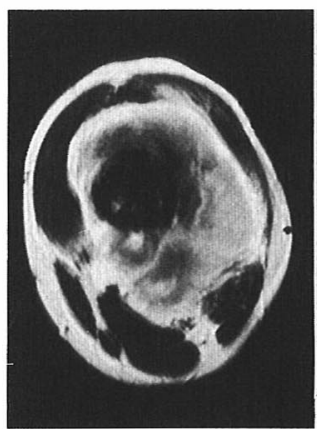

化学療法前

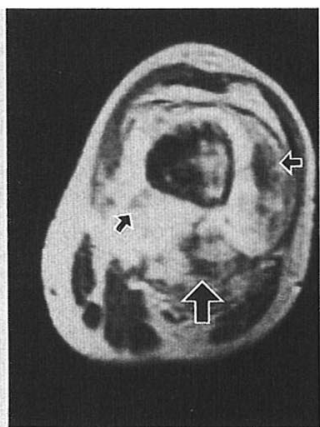

化学療法後
図 1 内部構造の变化 太い矢印が，壊死部分である，細い矢印は，壊 死以外の部分であり，これも low intensityを 呈している.

目 4 つと, 摘出標本の histological map より算出 した壊死率との相関関係を検討した.

$$
\text { 結果 }
$$

1. 内部構造の変化. MRI で腫瘍の壊死範囲がわ かれば手術での切除範囲決定の有力な情報となる．腫 瘍の壊死部分は T2 強調画像で low intensity を示す ので, T2 強調画像における low intensity area と histological mapにおける壊死範囲を比較検討した.
表 32 . 反応層の縮小

\begin{tabular}{|c|c|c|c|c|}
\hline \multicolumn{3}{|c|}{ 症 例 } & 反応層縮小 & 壊死率 \\
\hline 1 & \multicolumn{2}{|c|}{ (osteosarcoma) } & + & $50 \sim 90 \%$ \\
\hline 2 & ( & ) & + & $>90 \%$ \\
\hline 3 & ( & ) & 不 変 & $50 \sim 90 \%$ \\
\hline 4 & ( & ) & + & $<50 \%$ \\
\hline 5 & ( & ) & + & $>90 \%$ \\
\hline 6 & ( & ) & + & $50 \sim 90 \%$ \\
\hline 7 & ( & ) & + & $50 \sim 90 \%$ \\
\hline 8 & ( & ) & + & $>90 \%$ \\
\hline 9 & (Ewing sa & na) & + & $>90 \%$ \\
\hline
\end{tabular}

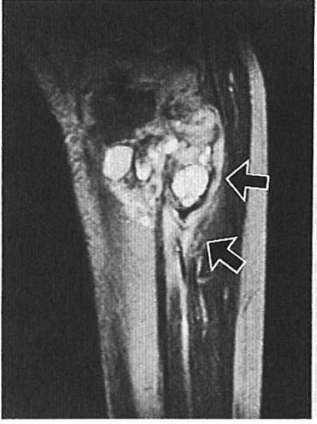

化学療法前

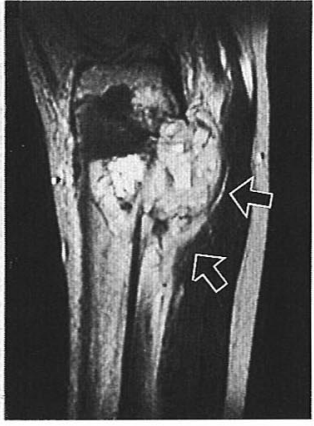

化学療法後
図 2 反応層の縮小

(症例 6 ：壊死率 $50 \%<<90 \%$ )

矢印で示す, high intensity zoneが, 化療後 では縮小している，ただし壊死率は $90 \%$ 以下 である。

その結果, 実際の壊死範囲以上にも, T2 強調画像で low intensity を示す部分があり，MRI で壊死範囲 を同定することは困難だと思われた。例えば図 1 に示 す症例においては, 術後の histological map と比 較した壊死範囲は大きい矢印で示す部分のみである。

しかし他にも小さい矢印で示すようにlow intensity を示す部分があり，壊死範囲のみの判定は困難である. T2 強調画像で low intensityを示すものとして, 1 . 壊死 2 . 骨形成, 石疢化 3 . 線維化 4 . 出血 (急性期のデオキシへモグロビン，慢性期のへモシデ リン）が挙げられる ${ }^{12)}$. 化療によって出現する骨形成, 線維化, 出血部分が腫瘍の壊死と同様に, low intensityを呈したものと思われる.

2 . 反応層の縮小. 一例を除く 8 例に反応層の縮小 がみられた。しかし壊死率 $90 \%$ 以下の 3 例中 2 例， $50 \%$ 以下の 1 例でもみられている（表 3 ）一般に，骨 
表 43 ，骨外腫瘤辺縁の明瞭化

\begin{tabular}{|c|c|c|c|c|}
\hline \multicolumn{3}{|c|}{ 症 例 } & 辺縁の明瞭化 & 壊死率 \\
\hline \multicolumn{3}{|c|}{1 (osteosarcoma) } & な L & $50 \sim 90 \%$ \\
\hline 2 & ( & ) & + & $>90 \%$ \\
\hline 3 & ( & ) & な し & $50 \sim 90 \%$ \\
\hline 4 & ( & ) & 混 在 & $<50 \%$ \\
\hline 5 & ( & ) & + & $>90 \%$ \\
\hline 6 & ( & ) & + & $50 \sim 90 \%$ \\
\hline 7 & ( & ) & 混 在 & $50 \sim 90 \%$ \\
\hline 8 & ( & ) & + & $>90 \%$ \\
\hline 9 & (Ewing sa & & $*$ & $>90 \%$ \\
\hline
\end{tabular}

* : 骨外病変ほとんどなく判定不能

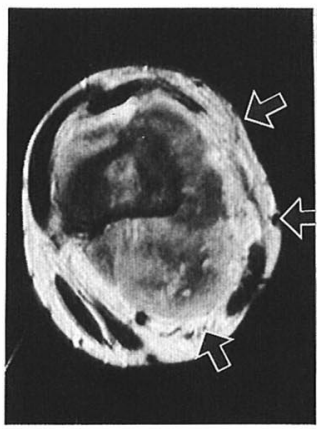

化学療法前

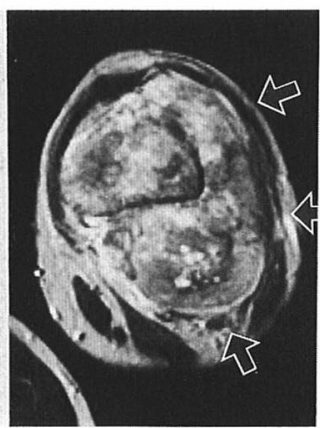

化学療法後

図3骨外腫瘤辺縁の明瞭化

（症例 17 : 壊死率 $50 \%<<90 \%$ )

矢印で示す腫瘍辺縁部の low intensity zone が化療後は明瞭になっている. しかし, それ以 外の部分では明暸化ははっきりしない.なお, 明 瞭化の認められない部分では腫瘍が増大している.

肉腫における化療に対する good responder とは壊 死率 $90 \%$ 以上のものであるから, 反応層の縮小とい う評価では, good responderよりも化療効果が悪 いものも効果ありとしてしまう可能性, 即ち, 甘めの 評価に陥る可能性がある. 図 2 の症例は, 壊死率 50 \%以上 $90 \%$ 以下であり, good responder とはいえ ない. しかし, 矢印で示す high intensity の部分が 化療後では縮小している.

3. 骨外腫瘤の辺縁の明瞭化. 症例 1,3 のうに 辺縁の明瞭化のないもの, あるいは症例 4,7 のよう に混在したものでは, $90 \%$ 以下の壞死率を示し, 少な くとも辺縁の明瞭化のないものでは壊死率は低い傾向 にあった (表 4 ). 図 3 の症例は, 壊死率 $50 \%$ 以上 90 \%以下で, 混在例である. 化療後は, 矢印で示す部分

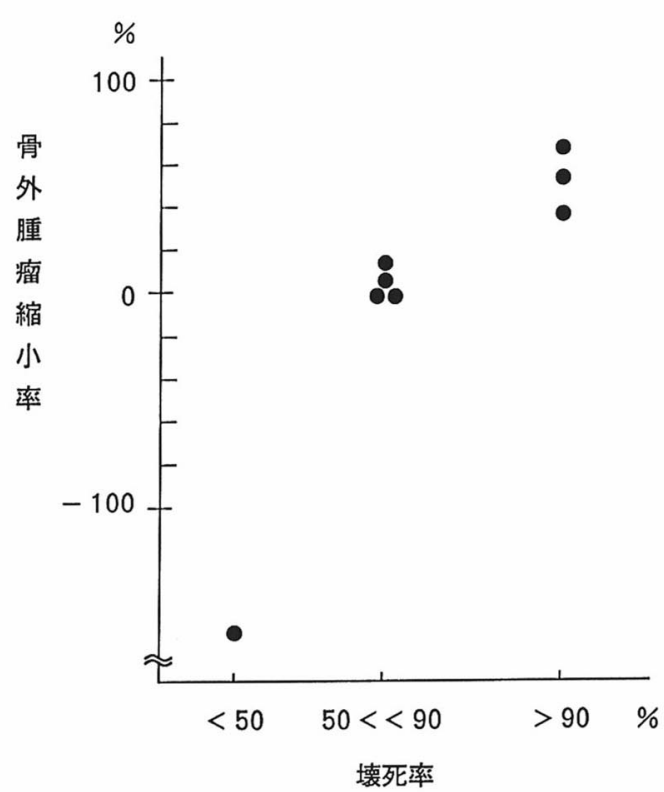

図 4 骨外腫瘤の縮小率

壊死率の高いものほど骨外腫瘤縮小率も高い.

には，骨外腫瘤の辺縁の明瞭化が認められるが, ほか の部分での辺縁の明暸化ははっきりしていない.

4. 骨外腫瘤の縮小. 骨外腫瘤の縮小率と壊死率と の関係を図 4 にまとめた，縮小率のマイナスは腫瘤の 増大を意味する。縮小率の大きいものでは壊死率 90 \%以上と有効例であったのに対し, 縮小率の小さいも の, あるいは増大したものは壊死率 $90 \%$ 以下と有効 ではなかった。

$$
\text { 考察 }
$$

骨軟部腫瘍の診断, 進展範囲の把握, 周辺組織との 関係，等に対して, MRI は非常に有力な検査法となっ た. そして現在, 化学療法の効果判定として何が最も 有用かというか議論 ${ }^{2)}$ の中, これを MRIに求めてみ たわけだが，先に述べた 4 つの項目のうち，1の内部 構造の変化, に対する報告は数多く見られる ${ }^{3)}$.8). Golden らは, 化療後の内部構造を 4 つのパターンに 分類し, それと, 壊死率との関係を調べている ${ }^{1)}$. 概 して,これらは化療後の壊死部分は T2 で low intensity を示すと述べている. また, 出血性変化は high intensity を呈するとの報告も有るが9)、11)，先に述べ たように出血も経時的に変化しており急性期でも 
low intensity を呈する場合があり，一時点での評価 は困難である。我々の結果でも，確かに壊死部分は low intensity を示したが, それ以外にも low intensity を示す部分があり，これらをすべて壊死部分と 評価するのは甘めの評価となり, 明確な壊死範囲のみ の同定は困難と思われた。また，放射線療法を行った 場合の T2 強調画像での high intensity は, 必ずし も腫瘍を示さないという報告もある7).これらのこと より，化療効果についての正確な質的診断を下すには, MRI はやや多彩な像を呈し過ぎているという印象を もった.

2. 反応層の縮小。これは, 壊死率の低い症例 (good responderではないもの) でもみられている. つまり，化療有効例でなくても反応層は縮小する場合 があり, 化療効果判定の指標としては不適当と思われ る.この反応層の縮小は, 化学療法前の腫瘍周辺組織 の, 腫瘍塊による圧迫や循環障害に伴う炎症や浮腫が, 化学療法や入院による安静により軽減されたことを反 映していると思われる.

3. 境界の明瞭化. これは, 反応層の内側に認めら れる low intensity zoneにより判定した。この low intensity zoneは, capsle の形成やこれに線 維化の加わったもの, 出血に伴うへモジデリンの沈着 などを反映したものと考えられる。この明瞭化の認め られないものには, 十分な化療効果は認められなかっ た。また, 混在例では, 壊死率の高い部分には明瞭化 が認められているのに対し，壊死率の低い部分では明 瞭化がはっきりとしていない.このことは, 切除範囲 決定（特に marginal margin）に際し有力な情報 となり得る。

4. 骨外腫瘤の縮小。これが壊死率と相関が高かっ たわけだが，これは臨床上で我々の一般的な主観，つ まり，見た目において腫瘍が縮小していれば化療効果 はある, といった印象を裏付ける結果となり, 病棟に 於いて用いている患肢周径の測定は, 簡便な評価法と して有用だと思われる。しかし，実際に化療前後の MRI 画像を比較すると, 化療期間中に腫瘍周囲の正 常筋組織の著明な萎縮が必発している. 即ち, 患肢の 周径は, 骨外腫瘤の縮小と, 筋の萎縮とを同時に評価 していることになる。この点からやはり，MRIにお ける骨外腫瘤面積の測定のほうが，患肢周径の測定よ りも正確な方法だといえるであろう。そして実際に,
デジタイザーで最大割面面積を求める際は, トレース 時，及びマウスで腫瘍外形を追う時に誤差を生じやす いため, 数回の測定の平均値を用いるとょり正確にな る. 理想的には, 腫瘍体積を求める方が望ましいが, 腫瘍の上，下縁の評価時に誤差が大きくなり易い，手 技的に繁雑でる，見た目での評価が困難，といった問 題点もあり，今後は，化療前と後で，同一スライス面 （なるべくaxial）での比較ができるような撮影を心 掛けることが重要である.

\section{ま と め}

悪性骨腫瘍 9 例を対象にMRIによる化療効果判定 を行った。

(1)内部構造 ; 明確な壊死範囲の同定は困難であった.

(2)反応層の縮小 ; 高率にみられたが，壊死率との相 関はなかった。

(3)骨外腫瘤辺緑の明瞭化 ; 不明瞭な例は有効例では なかった。

(4)骨外腫瘤の縮小; 壊死率と相関する.

\section{文献}

1) Golden,Pan. et al.: Radiology, $174: 517-526$, February 1990.

2）舘崎慎一郎・他：骨肉腫に対する術前化学療法の効果 判定. 日整会誌, 65(6)：677-684, 1991.

3) Herma,C.H. et al.: AJR, $154: 763-769$, April 1990.

4）岩本 幸英・他：骨軟部腫瘍の MRI一質的診断の可 能性一，整形外科と災害外科，39(4)：1714-1717，1991

5）岩本 幸英：骨軟部腫演の MRI．医学のあゆみ，vol. 152 No.11 : 696-699, 1990.

6）岩本 幸英・他：骨軟部腫瘍の診断における MRIの 有用性一CT 抄よび単純 X線との比較一。整形外科と災 害外科, $37(3)$ : 1237-1242, 1989.

7) Orthopaedic Knowledge Update 3, 115-129.

8) Robert,B,S. et al.: Radiology, $174: 237-240$, January 1990.

9）高橋 満-他：骨軟部腫瘍の MRI 診断. 整形外科, 41-3 : 349-355, 1990.

10）田仲 和宏・他：骨軟部腫瘍の MRI一軟骨系腫瘍に ついて一。整形外科と災害外科, $39(2): 638-642,1990$.

11）德海 裕史・他：骨軟部腫瘍における MRI の有用性 の検討. 整形・災害外科, $32: 969-976,1989$.

12）吉川宏起・他：MRI画像と整形外科疾患. 日整会 誌, 65(5)：382-394, 1991.

質 問福岡大学 諌山 照刀

(1) MRI とCT との比較をされましたでしょうか. 
(2) MRI と CT とで骨外腫瘤の差が出たでしょうか.

解 答学 山本 卓明

CTでは, Musclc とのコントラストがMRIに比
べ劣るため, 骨外腫瘤を観るために, 主に, MRI を 使用しました。

MRI と CT との比較はしておりません. 